\title{
Comparison of Some Selection Traits in Ewe in the Niger Delta Area of Nigeria
}

\author{
Okpeku M. Nodu M.B. and Ihegbulam C.P \\ Animal Science Department, Niger Delta University, Amassoma, Bayelsa State.
}

\begin{abstract}
The study was carried out in three different States in the South-South States of Nigeria; Delta, Bayelsa and Rivers States. A total of 150 mature female Sheep were sampled.The WAD is the smallest breed of the three breeds compared. The relationship between measured body traits and body weights of Sheep studied for this project showed high and significant values. Regression analyses showed high and significant predictive values for body weight using different linear body measurements.
\end{abstract}

Key Word: Ewe, Niger Delta, Sheep, Selection, Traits,

\section{Introduction}

Sheep are multifunctional animal that plays significant role in the economy and nutrition of landless, small and marginal poor farmers in most developing countries (Muhammad et al., 2006). The ability of to tolerate harsh climates, the presence of trypanotolerance and foot-rot resistance in some breeds (David-West, 1983; Hoste et al., I988; Salako, 2004), suitability to traditional systems on account of small size, short generation interval (Odubote, 1994) and ability to thrive on poor quality diets provided by scarce grazing on marginal lands (Hoste et al., 1988; Ozoje, 1998) all combine to make them strategic in increasing livestock productivity in rural agricultural systems (Fitzugh et al., 1992).

Mason (1981) reported that many small ruminant breeds today are falling victim to upgrading schemes as local breeds of livestock in many third world countries are being crossbred for improvement. This coupled with the uncontrolled breeding encouraged by extensive management system pose a great risk of genetic erosion and loss of valuable genes. Genetic improvement is currently being centered on indigenous breeds of livestock because they have long been adapted to extreme harsh environmental conditions of nutrition, climate and disease and as such, are expected to be more productive in their own environment than the exotic breeds (Maijala, 1983). They are also expected to be valuable experimental animals in basic livestock genetic research and a potential store of unique genes for improvement programmes, which may be useful especially when environmental concerns necessitate changes in production system (Salako and Ngere, 2002). However, there are no reports characteristics of the Nigerian Sheep found in the Niger Delta Area or the SouthSouth. Breed characterization and genetic improvement requires basic knowledge of genetic variations that can be effectively measured within and between populations (Okpeku et al. 2011); and are valuable traits for consideration in selection for breed improvement. Breeding flock consist of more female sheep (ewe) than male (ram) account for 80 to $90 \%$ of breeding flock and considered to be of more value than the ram; they carry young fetus and considered as channel of flock multiplication. There size and morphology are valuable indices considered during selection for breeding. This study was carried out to compare some selection traits in female sheep (ewe) in the Niger Delta area of Nigeria.

\section{Location of study}

\section{Materials and methods}

The study was carried out in three different States in the South-South States of Nigeria; Delta, Bayelsa and Rivers States.

\section{Experimental Animals}

A total of 150 mature female Sheep comprising 52 WAD, 32 Ouda, 28 Balami and 38 Yanka were sampled from University Farms and rural households in Delta, Bayelsa and Rivers States.

\section{Data collection}

Body length (BL): the distance from the occipital protuberance to the base of the tail.

Height at wither (HW): the height at wither was measured as the distance from the surface of the floor to the wither.

Heart Girth (HG): The body circumference around the heart region.

Tail Length (TL): extension of the tail from the point of connection to the trunk to the tip of the tail.

Body Weight (BW); the weight of individual Sheep using suspended weighing scale. 
All linear measurements were made in centimetre $(\mathrm{cm})$ and the body weight in kilogramme $(\mathrm{kg})$.

\section{Statistical Analyses}

Data were subjected to analyses using the mixed model of SAS Version 9.2 and the SPSS Version 10 statistical software. Means, standard errors and Standard deviation were calculated on all quantitative traits collected. Interrelationship of body weights and linear body measurements were estimated by simple correlation and simple linear regression (Steel and Torrie, 1980).

\section{Variation in measured quantitative traits}

\section{Results and discussion}

Mean values for measured body traits and body weight (Table 4), shows that the WAD Sheep is a smaller Sheep breed while the Ouda, Balami and Yankasa appeared to be heavier Sheep breeds. This is in Agreement with the report of Ngere et al. (1979), Osinowo et al. (1989) and Otoikhian (2008). It was also observed that the variation in phenotypic traits of Nigeria Sheep found in the Niger Delta area is relatively high. This is a good potential to explore for genetic improvement programmes fot Nigerian Sheep breeds.

\section{Relationship Between Body Linear Measurements and Body Weight of Sheep Studied}

The relationship between measured body traits and body weights of Sheep studied for this project (Table 5) showed high and significant values, which shows that they are highly correlated and suggests that an improvement in a body trait have potential possibility of also influencing an improvement in body weight. A similar deduction was reached by Okpeku, (2010) for similar studies in Nigerian goats.

\section{Prediction of Body Weight From Body Linear Measurements}

The results of regression analyses showed high and significant predictive values for body weight using different linear body measurements. This agrees with the report of Salako and Ngere (2002), Salako, (2004) and Salako et al. (2007). This is a valuable factor to rural farmers who often do not possess the right kind of weighing scales for their livestock, but could potentially deduce the live weight of their livestock from known body measurements which can be easily done using a simple measuring tape and known linear equations.

\section{Conclusion}

More females were sampled in the project accounting for $93 \%$ of the sampled populations. Eight coat colours were observed in this study suggesting some degree of heterozygosity at the colour loci.Correlation analysis showed that the relationship between body weight and body measurement traits was high and significant. Linear regression analysis also showed that body weight in Sheep can be predicted using different body measurement traits. The Nigerian Sheep breeds are well represented in the Niger Delta area of the South-South States where this research was conducted. Relationship between body weight and body linear traits studied suggest that they are mutual and an improvement in one will ultimately result in improvement of the other. Variation in body measurement and coat colour represent a diversity, high in heterosis that can be very useful in planning future breed improvement programmes in Sheep.

\section{Acknowledgement}

Fund for this Project was partly supplied from TETFUND Senate research grant 2012 awarded to Moses Okpeku.

\section{References}

[1]. David-West, K.B. 1983. Problems and prospects of livestock development in Nigeria. Nigerian Journal of Animal Production 10: 16 -23 .

[2]. Fitzugh, H.A., Ehui, S.K. and Lahlou-Kassi, A. 1992. Research strategies for development of animal agriculture. World Anim Rev. 72: $9-19$.

[3]. Hoste, CH, Chalon, E, D'leteren, G and Trail, JCM. 1988. Trypanotolerant livestock in west and central Africa. FAO Animal Health and Production Papers 20 (2): $56-67$

[4]. Maijala, K. 1983. Genetic diversity of European Livestock Breeds. In: Simon DL, Boucehuquer D. (eds). EAAP Publications, No 66.

[5]. Mason, I.L. 1981. Breeds. In goat production. Ed. By Gall C, London,UK, Academic press Inc. (London) Ltd. pp. 57-110.

[6]. Muhammad, F., Khan, H., Pervez, M., Nawaz, G. and Rahimulla. 2006. Body weight and body measurement in goats. Journal of Animal Veterinary Advances 5 (6) : 452-255 Ngere et al. 1979

[7]. Odubote, I.K. 1994. Characterization of the West African Dwarf goat for certain qualitative traits. Nigerian Journal of Animal Production. 21: $37-41$.

[8]. Okpeku, M. 2010. Population genetic structure and biodiversity of goats in South-Western Nigeria, PhD Thesis, University of Agriculture, Abeokuta. 
[9]. Okpeku, M., Ozoje, M.O., Adebambo, O.A., Agaviezor, B.O., O’Neill, M.J. and Imumorin, I.G. 2011. Preliminary analysis of microsatellite-based genetic diversity of goats in southern Nigeria. Animal Genetic Resources 49: $33-41$.

[10]. Osinowo, O.A., Olorunju, S.A.S., Otchere, E.O and Arigi, L.A. 1989. Development of weight band for Yankasa sheep and Red Sokoto goats. Paper presented at the $14^{\text {th }}$ Annual Conference of Nigerian Society for Animal Production held in Markurdi.

[11]. Otoikhian, C. S. O., Otoikhian, A. M., Akporhuarho, O. P., Oyefia, V. E. and Isidahomen C. E. 2008. Body measurement parameters as a function of assessing body weight in goats under on-farm research environment. African Journal of General Agriculture. 4 (3):135-140.

[12]. Ozoje, M.O. 1998. Coat colour genes in West African Dwarf sheep and goats: A theoretical appraisal. Proceedings, 6th World Congress of Genetics Applied to Livestock Production Vol. 26: 54 - 57.Robinet, 1967.

[13]. Salako, A.E. and Ngere, L.O. 2002. Application of multifactorial structural discriminant analysis in the morphometric structural differentiation of West African Dwarf and Yankassa sheep in South West Nigeria. Nigerian Journal of Animal Production 29(2): 163-167.

[14]. Salako, A.E. Ijadunola, T.O. and Agbesola, Y.O. 2007. Hemoglobin polymorphism in Nigerian indigenous small ruminant populations - preliminary investigation. African Journal of Biotechnology Vol. 6 (22) 2636-2638. http://www.academicjournals.org/AJB

[15]. Salako, A.E. 2004. Maturity rate of some morphometric traits in the West African Dwarf Sheep of Nigeria. Tropical Journal of Animal Science 7(1): 51-55.

[16]. Steel, R.G.D. and Torrie, J.H. 1980. Principles and Procedures of Statistics. 1st Edition McGraw - Hill, New York. pp. 107-109.

\begin{tabular}{lllll} 
Table 1. & Descriptive statistics of measured variables for female Sheep & by breed \\
\hline BREED & NUMBER & VARIABLE & MEAN $(\mathrm{cm} / \mathrm{kg})$ & Std. Error \\
\hline WAD & 52 & HW & 63.29 & 1.80 \\
& & HG & 70.15 & 1.08 \\
& & BL & 83.96 & 1.76 \\
& & TL & 27.25 & 1.48 \\
Ouda & \multirow{3}{*}{31} & BW & 24.04 & 0.88 \\
& & HW & 78.32 & 0.69 \\
& & HG & 78.48 & 0.66 \\
& BL & 95.26 & 0.88 \\
\multirow{3}{*}{ Balami } & TL & 40.39 & 1.02 \\
& \multirow{2}{*}{28} & BW & 29.71 & 0.75 \\
& & HW & 78.57 & 0.79 \\
& & HG & 76.82 & 0.60 \\
& & BL & 96.04 & 1.04 \\
Yankasa & TL & 39.93 & 0.93 \\
& & BW & 29.00 & 0.57 \\
& \multirow{3}{*}{38} & HW & 77.71 & 0.78 \\
& & HG & 78.02 & 0.78 \\
& & BL & 95.28 & 1.18 \\
& & TL & 39.05 & 0.69 \\
& & BW & 28.63 & 0.68 \\
\hline
\end{tabular}

Table 2. Correlation of body weight and body measurements for West African Dwarf (WAD) and Ouda sheep breeds

\begin{tabular}{|c|c|c|c|c|c|}
\hline & HW & $\mathrm{HG}$ & $\mathrm{BL}$ & $\mathrm{TL}$ & BW \\
\hline \multirow[t]{2}{*}{ HW } & & 0.911 & 0.877 & 0.920 & 0.777 \\
\hline & & $<0.01$ & $<0.01$ & $<0.01$ & $<0.01$ \\
\hline \multirow[t]{2}{*}{$\mathrm{HG}$} & -0.120 & & 0.835 & 0.881 & 0.822 \\
\hline & 0.52 & & $<0.01$ & $<0.01$ & $<0.01$ \\
\hline \multirow[t]{2}{*}{$\mathrm{BL}$} & 0.071 & 0.246 & & 0.875 & 0.788 \\
\hline & 0.72 & 0.18 & & $<0.01$ & $<0.01$ \\
\hline \multirow[t]{2}{*}{ TL } & 0.412 & 0.098 & 0.45091 & & 0.694 \\
\hline & 0.02 & 0.59 & 0.0109 & & $<0.01$ \\
\hline \multirow[t]{2}{*}{ BW } & -0.122 & 0.792 & 0.347 & 0.169 & \\
\hline & 0.51 & $<0.01$ & 0.06 & 0.36 & \\
\hline
\end{tabular}

WAD is represented above the diagonal and Ouda below the diagonal

Table 3. Correlation of body weight and body measurements for Balami and Yankasa Sheep breeds

\begin{tabular}{|c|c|c|c|c|c|}
\hline & HW & $\mathrm{HG}$ & $\mathrm{BL}$ & $\mathrm{TL}$ & BW \\
\hline \multirow[t]{2}{*}{ HW } & & 0.525 & 0.580 & 0.383 & 0.339 \\
\hline & & 0.00 & 0.00 & 0.04 & 0.07 \\
\hline \multirow[t]{2}{*}{$\mathrm{HG}$} & 0.293 & & 0.614 & 0.352 & 0.595 \\
\hline & 0.07 & & 0.00 & 0.06 & 0.00 \\
\hline \multirow[t]{2}{*}{$\mathrm{BL}$} & 0.505 & 0.611 & & 0.606 & 0.349 \\
\hline & $<0.01$ & $<0.01$ & & 0.00 & 0.07 \\
\hline \multirow[t]{2}{*}{ TL } & 0.646 & 0.124 & 0.343 & & 0.199 \\
\hline & $<0.01$ & 0.45 & 0.04 & & 0.30 \\
\hline \multirow[t]{2}{*}{ BW } & 0.071 & 0.706 & 0.385 & -0.026 & \\
\hline & 0.67 & $<.0001$ & 0.02 & 0.87 & \\
\hline
\end{tabular}


Balami is represented above the diagonal and Yakasa below the diagonal

\begin{tabular}{|c|c|c|c|}
\hline Breed & Dept Variable & R Square & Sig. \\
\hline \multirow[t]{4}{*}{ Ouda } & HW & 0.0151 & $<.0001$ \\
\hline & $\mathrm{HG}$ & 0.6277 & $<.0001$ \\
\hline & BL & 0.1203 & $<.0001$ \\
\hline & $\mathrm{TL}$ & 0.0284 & 0.0001 \\
\hline \multirow[t]{4}{*}{ WAD } & HW & 0.7287 & 0.0639 \\
\hline & $\mathrm{HG}$ & 0.8198 & $<.0001$ \\
\hline & BL & 0.6130 & $<.0001$ \\
\hline & $\mathrm{TL}$ & 0.6607 & $<.0033$ \\
\hline \multirow[t]{4}{*}{ Balami } & HW & 0.1154 & $<.0001$ \\
\hline & $\mathrm{HG}$ & 0.3540 & $<.0001$ \\
\hline & BL & 0.1215 & $<.0001$ \\
\hline & $\mathrm{TL}$ & 0.0397 & 0.0021 \\
\hline \multirow[t]{4}{*}{ Yankasa } & HW & 0.0495 & $<.0001$ \\
\hline & $\mathrm{HG}$ & 0.4759 & $<.0001$ \\
\hline & $\mathrm{BL}$ & 0.1360 & $<.0001$ \\
\hline & TL & 0.0008 & $<.0001$ \\
\hline
\end{tabular}

